DOI: $10.17516 / 1997-1370-0030$

УДК 324:17.002.010.15

\title{
Gender Features in Female Political Discourse: the Construction of Hillary Clinton's Political Image
}

\author{
Natal'ia S. Baikalova* \\ Siberian Federal University \\ Krasnoyarsk, Russian Federation
}

Received 12.02.2016, received in revised form 15.02.2016, accepted 10.08.2016

\begin{abstract}
Modern political campaign involves considerable efforts, which also include the creation of a political image. That is a complex process, which means elaboration of biography, character features, appearance and the style of speech. However, image making is a two-sided process, one side is a politician's behaviour and the second is media sources coverage of this behaviour. Recent research has shown the main features of male and female language styles and the gender markers, which women politicians employ for political campaigns. The materials for the analysis in this paper are the articles and analytical reports about Hillary Rodham Clinton. This paper is at the confluence of linguistics, politics and media discourse. The main goal of the research is to investigate which gender features journalists use for Hillary Clinton's representation in the media.
\end{abstract}

Keywords: Hillary Clinton, gender, woman's language.

Research area: politology.

Citation: Baikalova, N.S. (2021). Gender features in female political discourse: the construction of Hillary Clinton's political image. J. Sib. Fed. Univ. Humanit. Soc. Sci., 14(4), 584-591. DOI: 10.17516/19971370-0030.

\section{Гендерные особенности женского политического дискурса: создание политического имиджа Хиллари Клинтон}

\section{Н.С. Байкалова}

Сибирский федеральный университет

Российская Федерация, Красноярск

Аннотация. Предвыборная кампания любого политика подразумевает целый комплекс манипуляций с биографией кандидата, его манерой речи, внешним обликом

(C) Siberian Federal University. All rights reserved

* Corresponding author E-mail address: tata280792@mail.ru 
и репутацией. Однако конечный образ является не столько воплощением работы пиар-команды и поведением самого политика, сколько освещением и репрезентацией этого образа в средствах массовой информации. Статья посвящена вопросу гендерной идентификации политика в СМИ, тому, какая гендерная стратегия преимущественно избирается журналистами для освещения деятельности Хиллари Клинтон.

Ключевые слова: Хиллари Клинтон, гендер, женская речь.

Научная специальность: 23.00.00 - политология.

\section{Introduction}

The $21^{\text {st }}$ century is an epoch of equality. In western society the idea of gender formation prevails over the idea of sex predetermination. Nevertheless, our sex has an impact on parents' educational strategy. Every person inherits the language and the model of behaviour, which demonstrate the human characteristics. We segment such peculiarities and as a result we are to understand the personality. So, femininity and masculinity are two main blocks, which are important for comprehension. Still we cannot divide language into two groups -just the language of women and the one of men, we speak about intensity of femininity and masculinity of the language. There is no person, who uses canonical language without admixture from other discourses or other socially induced groups.

If we speak about the degree of femininity/masculinity in political connotation through the media network, we will see that in media sources the degree of femininity /masculinity is demonstrated as a stereotype about men and women in its pure form. Media sources aggravate the stereotypization in politics through accentuation on indigenously women's characteristics and roles, for examples, a mother, a wife, a guardian of the hearth, a teacher, and a seller. Listed roles are proven true by public opinion that such political posts as a Minister of Health; a Minister of Social Services, of Citizenship and Immigration, a Minister of Public Relations, a Minister of Maternity and Child Welfare Service and a Minister of Education are associated with women (Shvedova, 2002). The number of women, represented in the national parliaments was on the average of 17 percent all over the world in 2010, these data is far less than the number of men in the top government echelons (Inter-Parliamentary Union, March 2015, "Sluggish progress on women in politics will hamper development"). For our research we chose Hillary Diane Rodham Clinton, who started her career from the role of a wife and a mother, but became a Secretary of State in the most powerful country.

\section{Theoretical framework}

Gender studies became a widespread trend in the second part of the $20^{\text {th }}$ century as a reaction on the first wave of feminism, when for the first time ever women demanded a suffrage. Despite the long way of this concept to its modern representation, the first view was the same as the sex, well-known as a biological one. That "biological" term was driven by the typical vision on women's position in the society, it was thought that women could not participate in social life because their nature, their brain could not function like men's. That judgment was not scientifically motivated, but was a part of a whole epoch. When gender studies came into existence, the global point of view on gender nature moved from biological to social. Today perception is confirmed by the World Health Organization and there are many researchers, who we rely on. R. Lakoff deals with political correctness and public apologies, but the main issue is the peculiarities of women's speech (Lakoff, 1975). A. Haas specializes in differences between male speech and female speech (Haas, 1979). D. Zimmerman and C. West study the connection between biological and social in gender, they are specialized in "doing gender" concept (Zimmerman, West, 1987). J. Coates wrote such papers as "Women, Men and Language" (1986), "Women in their Speech 
Communities" (1989), “Women Talk. Conversation between Women Friends" (1996), and "Language and Gender: A Reader" (1998), her focus is on childhood and its characteristics in separate gender groups. M. Conrick works in the field of sexual harassment and gender and linguistic stereotyping mostly in Canada (Conrick, 1996). D. Tannen focuses on dominance and power in communication and on miscommunication between two genders in conversation (Tannen, 1991). S. Romaine writes about gender linguistics on grammatical and lexical levels (Romaine, 2005). D. Cameron is a popularizer of gender linguistics, she wrote the book "The Myth of Mars and Venus: Do Men and Women Really Speak Different Languages", which became a cycle of articles in the Guardian, also she has several programmes on $\mathrm{BBC}$ radio, one of which is "Woman's Hour" (Cameron, 2010).

\section{Methods}

For the purposes of this paper we firstly analyzed the distinctions between male and female language in general, then, placed them on the political area and analyzed how that transformation can be represented in the media discourse. The next step was the analysis of extracts from the articles about Hillary Clinton. We chose 10 sources: The Wall Street Journal, the ABC news, the New York Magazine, the Forbes, the New York Times, the USA Today, the USA news, the Business Insider, the Washington Post, the Los Angeles Times and the web-site of White House. In the end, we compared the general male and female peculiarities with phrases and words, which directly constructed the image of Hillary Clinton as a woman-politician and finally we totalized which gender strategy prevails in Clinton's image construction. The image construction in this paper implicates not all the techniques, which politicians use, but only those specific phrases and words, which can influence people's perception of a politician.

\section{Analysis of the material}

One of the most famous gender scientists D. Tannen induced an essential postulate for linguistics: two genders exploit language and speech because of two different reasons. Men's cause is keeping influence, status and making an arrangement. Women, by contrast, use language for establishment of communication, for relationship maintaining and "to be liked" (Tannen, 1991). Nevertheless, political context assumes that communication and language in the frames of state management has both goals - influence and a persuasion as well as communication and attraction, that is why, we are to find out distinguishing features in women's and men's language to understand if there are any differences in structure of languages of two genders or we have the differentials only in the targets.

The first distinction is the use of adjectives. The majority of gender researchers pinpoint attention upon ones in speech of two genders, the differences between which were repeatedly corroborated by experiments, which are based on R. Lakoff's research "Language and Woman's place", although dating 1975, having become classical (Lakoff, 1973). A. Haas with reference to O. Jesperson, R. Lakoff and C. Kramer consolidated that a woman makes use of adjectives more frequently than men and always emotionally - estimatively (Haas, 1979). R. Lakoff uses the word "empty" for description. Women often express their regard to saying, using empty adjectives, for example, "pretty", "cool", "divine", "precious", "lovely" and "cute". Such words can be a reaction on any case, whereas men, in the majority, express more complete and complex point of view. Use of adjectives by women gives the impression of infantilism and incompetence from the speaker's point of view. Apparently, journalists use that sort of descriptive adjectives to create an image of a faint and flippant politician. If the wish of a journalist is creation of an image of a professional woman-politician, all adjectives are to be neutral or hard and "strong", in other words, they should be male. Despite many research and evidence that men and women are originally equal, gender discourse presupposes discrimination. But it is not scientifically determined, contrariwise, public opinion is unnegotiable, ordinary people all over the world divide language into good and bad, into women's and men's. For emancipat- 
ed western countries it sounds as an outdated fact, however, when women's qualities are escribed to men, men react negatively. But when men's qualities are attributed to women, modern community encourages that. The case is more complicated in the political sphere. The image of a woman-politician depends on her representation in media mostly, and excessive femininity in speech can become a problem for her embracement by the public as a serious politician.

The other distinction is the use of politeness words, and hyper formal structures, both lexical and grammatical. It can be connected with a social role of a woman. Traditionally, she spends a lot of time with a child, so aspires to bring up a polite and kind child, that is why, mother reads books, tries to speak a correct language. During a girl's upbringing, parents usually speak according to literary language norms, at the same time, while boy's parenting, parents' speech is simple (Potapov, 2000).

The third difference is correctness. Turning to political reality, hyper correct and polite speech can be estimated as a distance from nation and, presumably, the public expects distinct and well-coordinated actions from politicians, but politeness and absolutely correctly constructed speech cannot create an impression of a leader.

The next divergence which $\mathrm{R}$. Lakoff pointed out is a fact that women use more questioning forms while men prefer confirmations. Abundance of questions has an adverse effect on women's political image. Journalists are capable of presenting plenty of questions not as a strive to cure a problem, but as an inapprehension and a lack of qualifications.

Sequent distinction involves naming. R. Lakoff wrote about women's nomination in the New York Times and the Times newspapers. Men were represented as individuals due to their ranks, titles, profession or using last and first names or just last name. But women were considered as somebody's wife or with "Mrs", which means that women were represented through relation with men (Lakoff, 1973).

And one more contrast refers to the topics of conversations. H. Moore examined about 180 conversations of New York citizens and concluded that men speak about business, money and sports mostly and women's topics were about men, other women and clothing (Moore, 1922). In the 1970s results showed the main men's topic was politics, at the same time women avoided this topic as well as discussions about religion (Langer, 1970).

Below are the gathered data which illustrate the main differences between men and women in language use.

Therefore, the male features are simple but comprehensible words and phrases, speech is direct and deprived of linguistic surpluses, such as tag questions, empty adjectives and exclamations. The topics are material, the manner of representation is direct; name, last name and profession are normally used for nomination. Women are often indirectly nominated by "she" or by subaudition, femininity assumes emotional adjectives, talks about home and family, and clear grammar with the use of standard lexis.

The purpose of the practical part is to estimate what features prevail in the media representation of Hillary Clinton and determine what gender strategy is mostly used for representation of candidate Clinton - feminine or masculine. We analyzed articles in terms of gender features and semantic context to understand image connotation firstly. And then we separated Hillary's representation into several images.

We took articles from 10 most authoritative American editions which cited. One magazine made a quotation about Hillary: "the Russian president noted that he has always had "cordial conversations" with Clinton at international events. "When people push boundaries too far, it's not because they are strong but because they are weak," he said. "But maybe weakness is not the worst quality for a woman." (Henderson, the Telegraph, 05.06.14). The first phrase "cordial conversations" directly points out either on friendship or on feminine side of Hillary Clinton, who wants to establish close relations, who refers to feelings. We know from the international context that there is no amicability between Russian and American politicians, that is, we cannot conclude that Hillary is represented as a friend. Here Hillary is 
portrayed as "weak" because of the femininity. The second part of the quote is used in the indirect manner, without direct reference to Hillary. The phrase primarily creates an impression of womanhood by an emotional adjective "cordial" and indirect appeal, which fall within female features according to the Table 1. But there is an undertone in quote - although weakness is a female characteristic, Hillary converts her femininity into the political muscle, she uses her weakness for political expansion.

On the White House web-site in the article about Hillary it is written "Hillary's childhood in Park Ridge, Illinois, was happy and disciplined. She loved sports and her church, and was a member of the National Honor Society, and a student leader." That sentence is a very sensible for image construction - there is a balance between womanish and manlike. "Happy" is a neutral adjective, "disciplined" is more masculine. "She loved sport" -it said that Hillary is a strong personality, but at the same time "loved her church", it can be said she is a radiant and sinless, she was an honour role student, which associate with girls mostly. (Voyer, American Psychological Association, 29.04.2014), but was "a leader", that quality was historically men's. Turning to Table, neutral adjectives are considered to be masculine. According to the eights line, there is masculine sport and leadership, at the same time feminine church and honour role, which are mostly emotional. Having analyzed the article about Hillary's childhood, we came to conclusion, that she is represented by both strategies: feminine and masculine.

"The presumptive Democratic front-runner, started her campaign miles ahead of challengers. [...] Her popularity remains high despite the "emailgate" revelations that she used her own private email address and server while at the State Department instead of the government system, potentially making her correspondence vulnerable to hacking and foreign surveillance. She said she had regretted the decision and complied with government rules.'(The world's most powerful people, Forbes, 2015). That quote shows the candidate as an advanced politician, as a victim of her own negligence. Words "presumptive" and "potentially" create an impression of uncertainty and characterize Hillary as a person, who cannot predict the consequences of her actions. But taking into consideration the fact that she took over the responsibility for incident and apologized, it says that Hillary is a strong and willed politician.

"She is proposing bandaids to assuage the pain rather than fundamental changes that fix the source of the problem."(Goodman, Forbes, 25.11.15). This quotation is two-folded. On the one hand, Hillary is a healer, helper. On the

Table 1. The differences between language of men and women

\begin{tabular}{|c|c|c|}
\hline № & Male features & Female features \\
\hline 1 & $\begin{array}{l}\text { Distant, neutral adjectives } \\
\text { great/terrific/good/cool }\end{array}$ & $\begin{array}{l}\text { Frequent, emotional, empty adjectives } \\
\text { adorable/ charming/sweet/ lovely/divine }\end{array}$ \\
\hline 2 & $\begin{array}{l}\text { Men use simple grammar and often rude speech, } \\
\text { creative }\end{array}$ & $\begin{array}{l}\text { Clear grammar and lofty lexis, } \\
\text { more standard forms }\end{array}$ \\
\hline 3 & $\begin{array}{l}\text { Direct questions, } \\
\text { affirmative constructions }\end{array}$ & A lot of tags questions \\
\hline 4 & Use lessmodal forms & $\begin{array}{l}\text { Use more epistemic modal forms: perhaps; } \\
\text { sort of; probably }\end{array}$ \\
\hline 6 & Talk more about nature & Talk more about feelings \\
\hline 7 & Direct speech & Less assertive and less direct character of speech \\
\hline 8 & $\begin{array}{l}\text { Tend to use more slang, } \\
\text { profanity and obscenity, and } \\
\text { to talk about sports, money and business }\end{array}$ & $\begin{array}{l}\text { Tend to talk more about home and } \\
\text { family and to be more emotional and positively } \\
\text { evaluative }\end{array}$ \\
\hline 9 & Personal nomination & Indirect nomination \\
\hline
\end{tabular}


other hand, is a politician, who cannot solve the main problem. The aid associates with maternity and care, with something feminine. The decision making is more common for the head of the family, for man.

We analyzed these and many other articles about Hillary Clinton and noticed the tendency of a prevailing masculine features in the image construction. The majority of journalists pointed out on the male features of the character, which Clinton shows in political struggle. At the same time we analyzed articles, where Hillary was half represented or represented as a woman. Half representation means either Hillary's male and female features were just listed or that features were countered. The majority of articles with "just a woman" representation were devoted to scandals or events, where Hillary makes herself inaccurate.

So, the data showed three images, which are created by the media: Hillary Clinton as a professional, as a fighter or aggressor and as a woman.The first image is a professional. That image is neutral in general, but in political context it becomes a masculine image. Quotes demonstrate Hillary's man side, her leadership, strong character and professionalism, for example, "Clinton tends to struggle", "Democratic presidential candidate Hillary Clinton sharply criticized members of the U.S. Senate", "Mrs. Clinton rejected the idea of reintroducing huge numbers of American combat troops in the Mideast, as Republicans have urged", "She can be relentlessly efficient.", "She can seem insulated, hostile (especially to the media) and calculating". The plenty of verbs, adverbs and nouns in a sentence create an effect of "manliness", of a forcible woman-politician, where a politician is in big letters. "Struggle" is a word, which is associated with early men, who struggle for food, family and power (Cambridge Advanced Learner's Dictionary \& Thesaurus). The second phrase underlines Hillary's fearlessness, there is an impression that she is alone against the Senate. The next quote "Hillary rejected the idea" makes Hillary a big chief, who can decide on the issue of war and stand against republicans party, she is a warrior. "Relentlessly" is an adverb, which innately extrinsic for women as for mothers, the same connotation has a word "cruel" (Oxford dictionary). One more evidence of leader's characteristics of Hillary is a title of a book about Clinton "Leadership secrets of Hillary Clinton".

The next image is a fighter and an aggressor. This block of citations represents the character of men mostly, represents Hillary as a person, who is ready to act with severity, for example, "Mrs. Clinton is focused on capturing the nomination and has been contrasting herself with the Republicans", "She is going to win", "Hillary beats Trump or Cruz, but loses to Rubio or Carson", "It was encouraging to hear Mrs. Clinton bluntly demand that Turkey, a NATO ally...", "Clinton was an aggressor from the start", "She promised to pressure the government in Iraq to arm Sunnis and Kurds", "Hillary Clinton sought to sharpen the distinctions between her candidacy for president and that of Vermont Sen.", "She's like a bull stomping its hooves before a charge." The word "capturing" has a semantic connection with a war, with an attack, so Clinton is a person, who is ready to start the battle. Hilary "is going to win" assumes the participation in the war. The word "beats" has a close meaning with battle and she is a warmonger again. At the same time she "loses", but it is part of the war, it demonstrates Hillary as a fighter. Clinton "bluntly demand", that is an element of ultimatum. The phrase "promised to pressure" has a semantic of a danger, of aggression. The same terms are applicable to the phrase "sought to sharpen". More than that, Clinton has a direct nomination of an aggressor in several articles. In addition, journalists compare Hillary with a bull, with an animal, which is basically shown as an aggressive beast, willing to kill matador on the arena.

Together with masculine features, Clinton is characterized by journalists as a woman by traditional stereotypes about women's social roles, women's hobbies, interests and streaks of character, "Clinton's notes show her searching for videos on how to do a "fishtail bun" hairstyle and struggling to locate Showtime on her television.", "But she did, indirectly and deftly, contradict Mr. Obama's comments....", "Mrs. Clinton will weave in her own experiences as a mother and grandmother to try to persuade voters that she is best positioned to address in- 
come inequality and to aid the middle class.", "She doesn't directly say these schools push out these children", "Asked what she thinks, you suspect the bubble over her head asks: What do you want me to think?", "Embracing the title grandmother - rather than running away - makes her real.", "She complains that she was constantly criticized for showing too much feeling in public; She laughs raucously again, mirth appearing to be, incongruously, her way of acknowledging pain.", "She's part of a generation that had to navigate daily the sometimes-yawning gap between the expectations of friends, family, employers and their country" "She made space in an incredibly difficult campaign to say... I want that support, it is important to me". The character of a politician as a woman drowns by using the words, which associate with a stereotyped perception of a woman. In quotes above it puts emphasis on homemakers' hobby - television, videos and hairstyles. The focus is on family relations also, Hillary is represented as a grandmother and mother. In the analyzed articles we met repeated mentions about the role of Bill Clinton's wife. Moreover, attention of a reader is on adjectives that show representative feminine features: indirectly and deftly, incongruously. Herewith it is felt that Hillary is a person, who relies just on her own experience, not on facts, who desires to make herself agreeable for all, is a weak woman, who needs aid and support.

One more important aspect of Hillary Clinton's image construction is a nomination, which journalists use for her representation. Several British and American sources investigate the issue of Clinton's nomination and concluded that Hillary Clinton uses nomination for influence. To be a serious politician in the business environment she prefers high-status and reputable name. In the situation, when she wants to underline her femininity, to show her feeling of solidarity, she applies to father's Rodham. Concerning media's nomination, the full name is used just in the biographical articles, in other papers about current events journalists use "Hillary Clinton" nine times out of ten. Also we faced with naming "Mrs. Clinton" several times, but such wording was used together with "Ms." for all candidates-men. We also found a lot of articles with absolutely direct nomination, when the name of the post added to the name, for example, "Former Secretary of State Hillary Clinton" or "Democratic presidential front-runner Hillary Clinton". At the same time we encountered several articles, where used "Hillary" naming and all they were the narration of Hillary's friends or familiars. It is notable that in the article about Clinton on the site of the White House, nomination is built by clear order: before entering the college she is "Hillary Rodham" or "Hillary Diane Rodham", then she is "Hillary" even after the wedding with Bill Clinton and only after New York Senator's election she became "Hillary Clinton". According to such a way of nomination the last name is a bonus for a political status. Today Hillary Clinton is a famous politician, that is why, journalists underline her status by full nomination. On the premise that direct naming prevails in the articles, we can say that nomination is not feminine, and taking into consideration the fact that for men's nomination combination of name and surname used mostly than name only, we conclude that nomination of Hillary is masculine to a greater extent.

On the basis of the conducted analysis we believe that the main tendency of Hillary Clinton's political image construction is prevailing of masculine manner of representation. The feminine description was used mostly for showing Clinton's weak spots and sometimes for approaching with women's part of electorate.

\section{Conclusion}

Every person has gender frames, but those frames change in the political context, because politicians adjust their behaviour according to the image. The most important part of the image constructing is media sources, and our task was to define what gender strategy of representation is used to form the public representation of Hillary Clinton. In the texts about Hillary Clinton journalists used neutral adjectives, pointed out on direct wordings, on topics about sports, business and used personal nomination, all those points are from the "masculine" group. At the same time, we 
met several emotional adjectives, some modal forms, few mentions about feelings, several references on family and a kind of indirect nomination. We concluded that Hillary Clinton was represented mostly as a masculine politician. We also defined Hillary Clinton's political images: a politician - professional, a politician - aggressor and a politician - woman. Moreover, we saw the overrepresentation of traditionally men's features over the image of a woman, so, in a greater degree Hillary Clinton has a masculine image and she is a professional politician firstly and after all the others a woman-politician.

\section{References}

Cameron, D (2010) "Sex/gender, language and the new biologism". Applied Linguistics 31. 2: $173-92$.

Conrick, M. Gender and linguistic stereotyping. Women Staff in Irish Colleges NUI, Higher Education Equality Unit, 1996, p. 70-78.

Haas, A. Male and female spoken language differences: Stereotypes and evidence., Psychological Bulletin, 1979, Vol 86(3), pp.616-626. Available at: http://dx.doi.org/10.1037/0033-2909.86.3.616

Lakoff, R. Language and Woman's Place: Text and Commentaries. Oxford University Press, 2004.320 p.

Philips, S.U., Review of Jennifer Coates, and Deborah Cameron 'Women in their speech communities' (1990) Language in Society, 19, pp 547-550.doi:10.1017/S0047404500014822.

Potapov, V. Popytki peresmotra gendernogo priznaka v angliiskom iazyke [Attempts to revise gender characteristicsin English language]. Sbornik statei mezhdunarodnoi nauchnoy konferentsii "Gender kak intriga poznaniia" (Proc. Int. Symp. "Gender as an intrigue of perception"). Moscow, 2000, p. 84-92.

Romaine, S. Language and gender. Linguistic Anthropology. Encyclopedia of Life Support Systems (EOLSS).Developed under the auspices of UNESCO. Oxford: Eolss Publishers, 2005. Available at: http:// www.eolss.net.

Rosenfeld, E.T. Review of Jennifer Coates 'Women, men and language: a sociolinguistic account of gender differences in language' (1995) Studies in Second Language Acquisition, 17, p. 103-103. doi:10.1017/ S0272263100013887.

Shvedova, N. Prosto o slozhnom: gendernoe prosveshchenie [Simply about the complex: gender education]. Moscow, Antikva Publ., 2002, p. 1-150.

Tannen, D. You Just Don't Understand: Women and Men in Conversation. Ballantine, 1991. 330 p.

Tannen, D. Gender and Discourse. Oxford University Press, 1996. 240 p.

West C., Zimmerman Z.H., Doing Gender (1987) Gender \& Society, p. 125-151. doi: 10.1177/0891243 287001002002 